\title{
Localization of Kv1.1 and Kv1.2, Two K Channel Proteins, to Synaptic Terminals, Somata, and Dendrites in the Mouse Brain
}

\author{
Hao Wang, ${ }^{1,2}$ Dennis D. Kunkel,, ${ }^{3}$ Philip A. Schwartzkroin, ${ }^{3}$ and Bruce L Tempel ${ }^{1,2}$ \\ 'Geriatric Research Education and Clinical Center, VA Medical Center, Seattle, Washington 98108 and ${ }^{2}$ Departments of \\ Medicine and Pharmacology and ${ }^{3}$ Departments of Neurological Surgery and Physiology-Biophysics, University of \\ Washington School of Medicine, Seattle, Washington 98195
}

\begin{abstract}
Multiple voltage-gated potassium $(\mathrm{K})$ channel gene products are likely to be involved in regulating neuronal excitability of any single neuron in the mammalian brain. Here we show that two closely related voltage-gated $K$ channel proteins, $\mathrm{mKv} 1.1$ and $m \mathrm{mkv1.2}$, are present in multiple subcellular locations including cell somata, juxtaparanodal regions of $\mathrm{my}$ elinated axons, synaptic terminals, unmyelinated axons, specialized junctions among axons, and proximal dendrites. Staining patterns of the two channel polypeptides overlap in some areas of the brain, yet each has a unique pattern of expression. For example, in the hippocampus, both mKv1.1 and $\mathrm{mKv} 1.2$ proteins are present in axons, often near or at synaptic terminals in the middle molecular layer of the dentate gyrus, while only mKv1.1 is detected in axons and synaptic terminals in the hilar/CA3 region. In the cerebellum, both channel proteins are localized to axon terminals and specialized junctions among axons in the plexus region of basket cells. Strong differential staining is observed in the olfactory bulb, where mKv1.2 is localized to cell somata and axons, as well as to proximal dendrites of the mitral cells. This overlapping yet differential pattern of expression and specific subcellular localization may contribute to the unique profile of excitability displayed by a particular neuron.
\end{abstract}

[Key words: potassium channels, immunocytochemistry, mouse brain]

$\mathrm{K}$ channels play an important role in regulating the level of neuronal excitability. Voltage-gated $\mathrm{K}$ channels, in particular, function to shorten the action potential, to determine the frequency of repetitive firing, and to time the interspike intervals (Jan and Jan, 1989; Hille, 1991). The diversity of firing patterns displayed by neurons of the CNS is reflected in a wide variety of voltage-gated $\mathrm{K}^{+}$currents that differ in their kinetics, voltage dependence, pharmacology, single-channel behavior, and other

\footnotetext{
Received Aug. 18, 1993; revised Dec. 27, 1993; accepted Jan. 13, 1994.

We thank Drs. M. M. Bosma, W. F. Hopkins, W. J. Spain, and O. A. Smith for comments on the manuscript. This work was supported by grants from The Bloedel Hearing Research Center (B.L.T.) and the National Institutes of Health (NS27206 to B.LT., NS15317 to P.A.S.). H.W. is supported by a predoctoral fellowship from the Keck Foundation.

Correspondence should be addressed to Bruce L Tempel, Geriatric Research Education and Clinical Center (182-B), VA Medical Center, 1660 S. Columbian Way, Seattle, WA 98108.

Copyright (C) 1994 Society for Neuroscience $0270-6474 / 94 / 144588-12 \$ 05.00 / 0$
}

properties (Rudy, 1988). Often, multiple types of $\mathrm{K}^{+}$currents can be found in the same cell, and similar types of $\mathrm{K}^{+}$currents can be found in different cells.

Molecular cloning of voltage-gated $\mathrm{K}$ channels from Drosophila has confirmed the presence of a diverse family of $\mathrm{K}$ channels (Kamb et al., 1987; Papazian et al., 1987; Tempel et al., 1987; Baumann et al., 1988; Pongs et al., 1988; Schwarz et al., 1988; Timpe et al., 1988; Butler et al., 1989). At least four subfamilics of voltage-gatcd $\mathrm{K}$ channcl gencs, homologous to the Drosophila genes Shaker, Shab, Shaw, and Shal, have been cloned from mammalian species (Tempel et al., 1988; Christie et al., 1989; Stühmer et al., 1989; Chandy et al., 1990; Swanson et al., 1990; Pak et al., 1991; Hwang et al., 1992). In situ hybridization and immunocytochemistry have demonstrated that several voltage-gated $\mathrm{K}$ channels are expressed in a cell-specific manner and are localized to specific subcellular regions (Trimmer, 1991; Drewe et al., 1992; Hwang et al., 1992, 1993; Sheng et al., 1992; Wang et al., 1993). This precise localization suggests that the expression of a specific $\mathrm{K}$ channel gene in a specific subcellular location is important for normal neuronal function.

$\mathrm{mKv} 1.1$ and $\mathrm{mKv} 1.2$ are two closely related $\mathrm{K}$ channels of the Shaker-like subfamily. When expressed in Xenopus oocytes, each of them gives rise to a fast-activating, slowly inactivating $\mathrm{K}^{+}$current. However, the two channels have different thresholds of activation and kinetics of onset and recovery from inactivation. When coexpressed in Xenopus oocytes, they form heteromultimeric channels with distinct properties (Hopkins, unpublished observations). This finding is in agreement with other reports that heteromultimeric channels can form within a $\mathrm{K}$ channel gene subfamily but apparently not between subfamilies (Christie et al., 1990; Isacoff et al., 1990; Ruppersberg et al., 1990; Covarrubias et al., 1991). The sequences responsible for specificity of assembly within the Shaker subfamily resides primarily in the hydrophilic $N$-terminal region (Li et al., 1992; Hopkins et al., 1993; Shen et al., 1993).

Recently, these results have been extended to show that $\mathrm{mKvl} .1$ and $\mathrm{mKv} 1.2$ proteins (Wang et al., 1993) as well as rKv1.2 and rKvl.4 (Sheng et al., 1993) can form heteromultimeric channels in vivo. Given that the cellular and subcellular locations of the two channels are likely to contribute to the unique firing pattern of a particular neuron, we have conducted a detailed immunocytochemical study of $\mathrm{mKv} 1.1$ and $\mathrm{mKvl} .2$ throughout the mouse brain. We find that some neurons express both $\mathrm{mKv} 1.1$ and $\mathrm{mKvl} .2$ in the same subcellular locations 
while others do not. The overlapping yet differential expression of mKvl.1 and mKvl.2 may thus contribute to the diverse firing patterns of the nervous system.

\section{Materials and Methods}

Immunocvtochemistry. Polyclonal antibodies recognizing mKvl.1 and $\mathrm{mKv} 1.2, \alpha-\mathrm{Kv} 1.1$ and $\alpha-\mathrm{Kv} 1.2$, respectively, were made and purified as described by Wang et al. (1993). Briefly, antibodies were made against fusion proteins containing either the carboxy terminus of $\mathrm{mKvl} .1$ (73

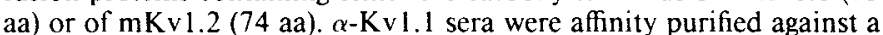
fusion protein containing the carboxy terminus of $\mathrm{mKvl} .1$, and then absorption purified against a fusion protein containing the carboxy terminus of mKv1.2. This procedure selected for antibodies that recognized $\mathrm{mKv} 1.1$ but did not recognize mKv1.2. Reciprocally, $\alpha-\mathrm{Kv} 1.2$ was affinity purified against $\mathrm{mKv} 1.2$; absorption purified against $\mathrm{mKv} 1.1$. Based on Western blotting and immunoprecipitation assays, no crossreaction was seen for either purified antibody among $\mathrm{mKv} 1.1, \mathrm{mKv} 1.2$, or $\mathrm{mKv1.3}$, the three most closely related voltage-gated $\mathrm{K}$ channel proteins of the Shaker-like subfamily.

Frozen sections $(35 \mu \mathrm{m})$ from six $\mathrm{C} 57 \mathrm{BL} / 6$ mice were cut on a sliding microtome. Free-floating sections were processed for immunocytochemistry using the indirect peroxidase-antiperoxidase (PAP) technique of Sternberger (1979) except that we used modified dilution buffer [3\% BSA $+3 \%$ normal goat serum, $0.4 \%$ dimethyl sulfoxide, 0.05 м TBS ( $50 \mathrm{~mm}$ Tris, $150 \mathrm{~mm} \mathrm{NaCl}, \mathrm{pH} 7.4)$ ] and longer incubation times (primary: $3 \mathrm{hr}$ at room temperature followed by $96 \mathrm{hr}$ at $4^{\circ} \mathrm{C}$; rabbit IgG: $2 \mathrm{hr}$ at room temperature followed by $48 \mathrm{hr}$ at $4^{\circ} \mathrm{C}$; rabbit PAP: $2 \mathrm{hr}$ at room temperature followed by $24 \mathrm{hr}$ at $4^{\circ} \mathrm{C}$ ) to ensure complete tissue penetration by the antibodies. The antisera concentrations used were $\alpha-\mathrm{Kv1} 1$ and $\alpha-\mathrm{Kv} 1.2,1: 40$; goat anti-rabbit IgG, 1:150; and rabbit PAP, 1:250. The peroxidase/diaminobenzidine reaction was performed as previously described (Itoh et al., 1979). Sections were mounted on polylysine-coated slides. As a negative control, sections were stained with antibodies preabsorbed with GST-1.1 or GST-1.2 fusion proteins as described by Wang et al. (1993).

Electron microscopic (EM) immunocytochemistry. Immunostaining reactions are conducted similarly as for light microscopy except that 80 $\mu \mathrm{m}$ sections were used. Following the immunostaining reaction, the sections were processed for EM as follows: sections were rinsed in 0.1 M sodium cacodylate $(0.5 \mathrm{hr})$, and then postfixed with $1 \% \mathrm{OsO}_{4}$ in 0.15 M sodium cacodylate $(1 \mathrm{hr})$, rinsed, dehydrated, and flat embedded in Medcast resin. Serial ultrathin sections (silver to light yellow interference color) were cut, stained with uranyl acetate and Reynolds lead citrate, and examined on a Philips 410 electron microscope.

In situ hybridization. Young adult C57BL/6 mice were decapitated, brains were carefully removed, and rapidly frozen in dry ice. Frozen sections $(20 \mu \mathrm{m})$ were cut on a cryostat, then mounted onto 3-aminopropyltriethoxysilane-treated slides, air dried, and fixed with $4 \%$ paraformaldehyde in PBS $\left(0.15 \mathrm{M} \mathrm{NaCl}, 0.1 \mathrm{M} \mathrm{NaPO}_{4}, \mathrm{pH} 7.4\right)$ for $10 \mathrm{~min}$, and then briefly rinsed with PBS. The sections were acetylated with $0.25 \%$ acetic anhydride in $0.1 \mathrm{~m}$ triethanolamine $(\mathrm{pH} 8.0)$ for 10 min followed by dehydration through a graded alcohol series $(70 \%, 95 \%$, and $100 \%$ ), delipidation in chloroform for $5 \mathrm{~min}$, and treatment with $100 \%$ and then $95 \%$ alcohol. Sections were hybridized at $50^{\circ} \mathrm{C}$ in hybridization solution ( $50 \%$ formamide, $10 \%$ dextran sulfate, $0.3 \mathrm{M} \mathrm{NaCl}$, $10 \mathrm{~mm}$ Tris, $1 \mathrm{~mm}$ EDTA, $10 \mathrm{~mm}$ DTT, $200 \mathrm{mg} / \mathrm{ml}$ yeast tRNA, and $2 \mathrm{pmol} / \mathrm{ml}$ cRNA probes) with siliconized coverslips in a moist chamber. The coverslips were removed by brief rinsing in $2 \times$ SSC. Sections were then treated with $20 \mathrm{mg} / \mathrm{ml} \mathrm{RNase} \mathrm{A} \mathrm{in} \mathrm{RNase} \mathrm{buffer}(0.01 \mathrm{M}$ Tris, $0.5 \mathrm{M} \mathrm{NaCl}, 1 \mathrm{~mm}$ EDTA) for $30 \mathrm{~min}$ at $37^{\circ} \mathrm{C}$, rinsed with $2 \times$ SSC, and then $0.1 \times \mathrm{SSC}$ at $55^{\circ} \mathrm{C}$ for $1 \mathrm{hr}$. Finally, sections were dehydrated through a graded series of ethanol containing $0.3 \mathrm{~mm}$ ammonium acetate and air dried. Slides were dipped in Kodak NTB-2 emulsion (diluted $1: 1$ in water), stored at $4^{\circ} \mathrm{C}$ for $10 \mathrm{~d}$, developed, and counterstained with hematoxylin bluc.

The cRNA probe (riboprobe) for mKvl.1 was transcribed with T7 RNA polymerase from a plasmid that contains 252 base pair (bp) of mKv 1.1 sequence corresponding to $40 \mathrm{bp}$ of 5 untranslated region and $212 \mathrm{bp}$ from the amino terminal coding region. The cRNA probe for mKv1.2 was transcribed with T3 RNA polymerase from a plasmid containing $250 \mathrm{bp}$ of the $3^{\prime}$ untranslated region and $135 \mathrm{bp}$ of the carboxyl terminus of $\mathrm{mKv} 1$.2. Each of these probes was shown to detect specifically the appropriate transcript on RNA (Northern) blots (data not shown). Riboprobes corresponding to sense-strand sequences from the same regions were used as negative controls; no specific staining was observed (data not shown).

\section{Results}

General distribution of the $m K v 1.1$ and $m K \forall 1.2$ proteins in the mouse brain

Each potassium (K) channel protein - mKv1.1 and mKv1.2has a unique pattern of distribution in the mouse brain (Fig. $1 a, b$ ). Besides their widespread presence in the juxtaparanodal regions of many myelinated axons throughout the brain (Wang et al., 1993; Fig. 1k,l; Table 1), mKv1.1 and mKv1.2 proteins are also distributed in cell somata, unmyelinated axons, axon terminals, specialized junctions in axons, and in dendrites in specific areas of the brain.

In neocortex, both $\mathrm{mKv} 1.1$ and $\mathrm{mKv} 1.2$ proteins are detected in fibers and neuropil (Figs. $1 c-f, 2 g, h$ ). mKvl.1 staining is also present in a number of pyramidal cell somata in layers II, III, and $\mathrm{V}$, with the most dense staining in somata of layer $\mathrm{V}$ (Fig. $2 g$ ). Staining also appeared to associate with the apical dendrites of the pyramidal cells of layer V. In situ hybridization of $\mathrm{mKvl} .1$ shows strong expression in layer II, III, and V (data not shown; also see Tsaur et al., 1992), supporting the view that the $\mathrm{K}$ channel proteins may be located within the dendrites. However, given the complex presynaptic input to the pyramidal cells, we cannot exclude the possibility that the staining may reflect expression in presynaptic terminals. Staining for $\mathrm{mKv} 1.2$ protein was similar to that observed for mKv1.1 in the neuropil; however, mKv1.2 channel protein was not observed in somata of the neocortex (Fig. $2 h$, Table 1).

In the neostriatum, distinct patterns of $\mathrm{mKvl} .1$ and $\mathrm{mKv} 1.2$ expression are seen: (1) $\mathrm{mK} v 1.1$ has a strikingly high level of expression in the ventral pallidum (Vp) region (Fig. $1 c, g$ ), while mKv1.2 staining is not observed in Vp (Fig. le); (2) mKv1.1 is cxpressed at a relatively high level in the globus pallidus compared to the caudate/putamen region (Fig. $1 c$ and, more caudally, Fig. $1 d$ ), while mKv 1.2 is expressed at approximately the same level in both regions (Fig. $1 e$ and, more caudally, Fig. $1 f$ ); and finally, (3) mKvl.1 stains heavily in entopeduncular (Ep) nucleus, reticular thalamic nucleus and ventral posterior lateral (VPL), and ventral posterior medial (VPM) nuclei of the thalamus (Fig. 1d), while $\mathrm{mKv} 1.2$ stains more heavily in the habenular nucleus (Ha in Fig. $2 c, d$ ) and ventral lateral nucleus of the thalamus (Fig. $1 f$ ).

In the brainstem, both $\mathrm{mKv} 1.1$ and $\mathrm{mKv} 1.2$ stain heavily in the juxtaparanodal regions of myelinated axons (Wang et al., 1993). Both channels are localized in cell somata in some nuclei, e.g., soma within the cochlear nucleus (Fig. 3a,b,d). However, as in the neocortex, $\mathrm{mKv} 1.1$ stains more cell bodies than $\mathrm{mKv} 1.2$ and does so in a number of brain regions including the nucleus of the trapezoid body (Fig. 3e), mesencephalic trigeminal nucleus, principle sensory trigeminal nucleus, pontine reticular nucleus, spinal trigeminal nucleus, and vestibular nuclei (Fig. $3 a, b$; Table 1).

The regional expression patterns of $\mathrm{mKvl} .1$ and $\mathrm{mKv} 1.2$ are summarized in Table 1 . In general, the pattern that emerges from this survey shows that staining by $\mathrm{mKv} 1.1$ is often prominent in cell somata, while staining by $\mathrm{mKv} 1.2$ is often equally strong if not stronger in many fiber tracts and regions of neuropil.

As observed in the juxtaparanodal regions of the node of Ranvier (Wang et al., 1993), the immunoreaction products of $\mathrm{mKvl} .1$ and $\mathrm{mKvl} .2$ are seen associated with the axon membrane as well as being present in the underlying cytoplasm (Fig. 

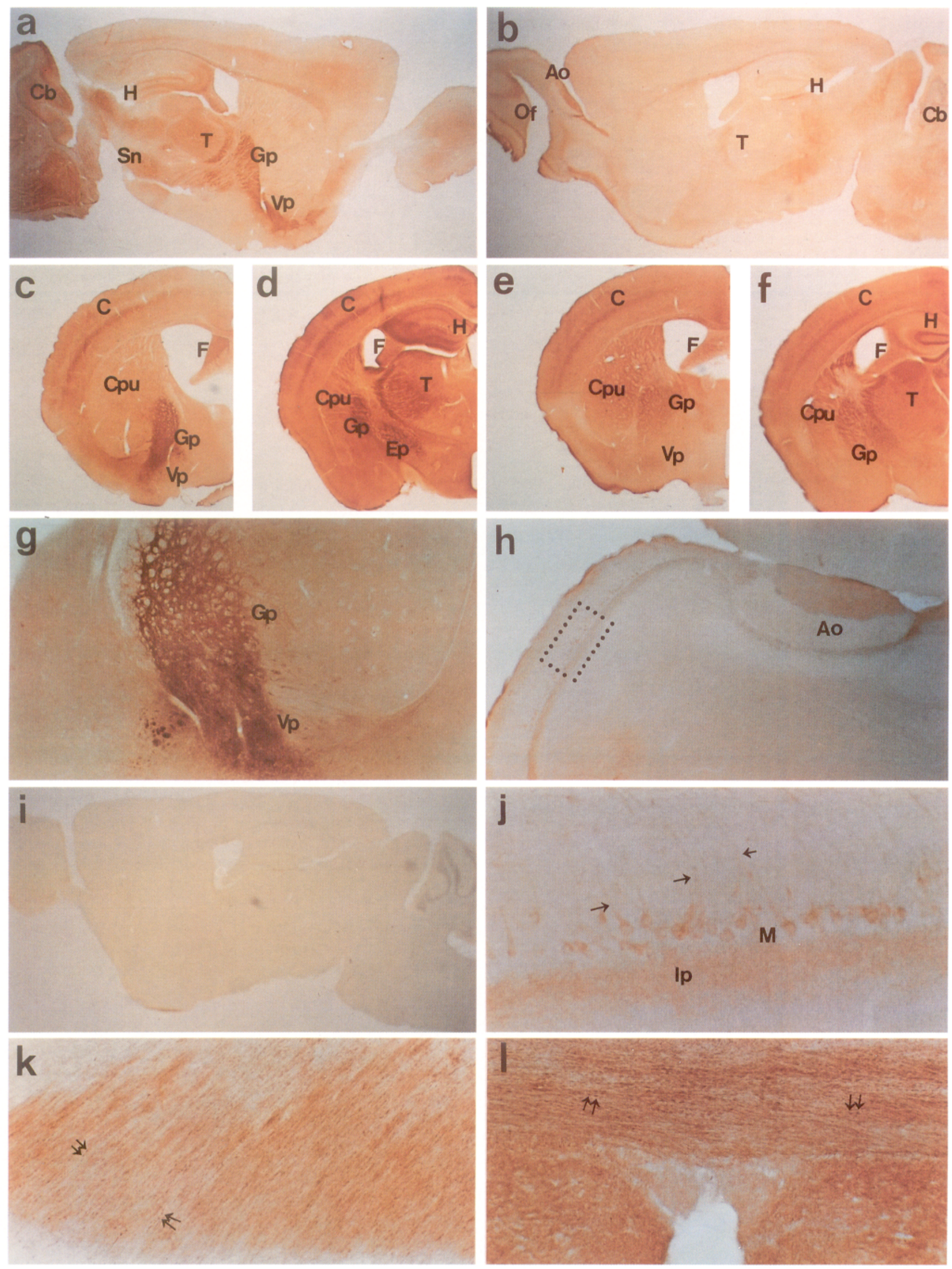
Table 1. Immunocytochemical localization of $\mathrm{K}$ channel proteins

\section{mKv1.1}

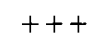

Cell bodies

Fiber tract or

neurophil

Proximal dendrites

\section{Cerebellar nuclei}

Cochlear nucleus, dorsal and ventral

Diagonal band, nucleus

Intermediate gray layer of superior colliculus, nucleus

Lateral superior olive

Medial septal nucleus

Mesencephalic trigeminal nucleus

Motor trigeminal nucleus

Neocortex

Olfactory bulb mitral and tufted cells

Peritrigeminal zone

Pontine reticular nucleus

Principal sensory trigeminal nucleus

Raphe pontis nucleus

Trapezoid body, nucleus (medial)

Ventral pallidum

Vestibular nuclei

Anterior commissure

Caudate/putamen

Corpus callosum

Dentate gyrus (middle molecular layer)

Entopeduncular nucleus

External medullary lamina

Fasciculus retroflexus

Fornix

Globus pallidus

Habenula

Hippocampus (CA3/hilar region)

Medullar fiber tracts

Optic tract

Reticular thalamic nucleus

Stria terminalis

Substantia nigra

Ventral lateral nucleus of thalamus

Ventral pallidus

VPL + VPM of the thalamus

Mitral cells

Dorsal and ventral cochlear nucleus

Pontine reticular and spinal trigeminal nuclei

Pyramidal cells in neocortex

$\begin{array}{ll}++ & + \\ +++ & ++\end{array}$

$+++\quad++$

$++\quad-$

$++$

$++$

$++\quad-$

$+++\quad \pm$

$+++$

$++\quad-$

$-\quad+++$

$+++\quad-$

$++++ \pm$

$++++$

$++\quad-$

$++\quad \pm$

$++\quad-$

$+++$

$++\quad+$

$\pm \quad++$

$++\quad++$

$+++\quad++$

$+++\quad+$

$+++\quad++$

$-\quad+++$

$++\quad++$

$++\quad++$

$-\quad++++$

$+++$

$+++t+$

$+++t+$

$+++\quad+++$

$+++\quad+$

$+++\quad-$

$\pm \quad++$

$++++$

$++\quad \pm$

$-$

$++\quad+$

$++$

$\pm \quad-$

Figure 1. General immunohistological localization of mKv1.1 (left column) and mKvl.2 (right column) in the mouse brain. $a$, Sagittal section stained with $\alpha-\mathrm{Kv}$ l.1. Labeled structures include hippocampus $(H)$, thalamus $(T)$, globus pallidus $(G p)$, ventral pallidus ( $V p)$, substantia nigra $(S n)$, cerebellum $(C b) . b$, Sagittal section stained with $\alpha$-Kvl.2. Abbreviations are as in $a$, with the addition of olfactory bulb $(O f)$ and accessory olfactory bulb $(A o) . c$ and $d$, Coronal sections stained with $\alpha-\mathrm{Kv} 1.1$ ( $d$ more caudal than $c$ ) showing the immunoreactive signal in the cortex $(C)$, hippocampus $(H)$. globus pallidus $(G p)$, entopeduncular nucleus $(E p)$, thalamus $(T)$, ventral pallidum $(V p)$, caudate/putamen $(C p u)$ and fornix $(F)$. Note the more intense staining in $\mathrm{Gp} / \mathrm{Vp}$ than in $\mathrm{Cpu}$. $e$ and $f$, Coronal sections stained with $\alpha-\mathrm{Kv} 1.2(f$ more caudal than $e$ ). Labels as above. Note absence of staining in ventral pallidum $(\mathrm{Vp})$ and hilar/CA3 region of the hippocampus $(H) . \alpha-\mathrm{Kvl} .2$ stains the caudate/putamen $(C p u)$ and globus pallidus $(G p)$ with similar intensity. $g$. Higher magnification of the staining pattern for $\alpha-\mathrm{K} v 1.1$ in the globus pallidus $(G p)$ and ventral pallidum $(V p)$. $h$, Immunoreaction signal of $\alpha-\mathrm{Kvl} .2$ in the olfactory bulb showing signal in the mitral cell layer and internal plexiform layer (boxed) as well as in the accessory olfactory bulb $(A O)$. $i$, Sagittal section stained with $\alpha-\mathrm{Kv} 1.1$ preabsorbed with GST-1.1 fusion protein as a negative control. $j$, Higher magnification of boxed region in $h$. Note $\alpha-\mathrm{Kv} 1.2$ staining in the proximal dendrites (arrows) of the mitral cells $(M)$ and in the inner plexiform layer $(I p) . k$. Fornix stained with $\alpha-K v 1.1$. Note the paired punctate staining at juxtaparanodal regions (arrows). $l$, Corpus callosum stained with $\alpha-K v l .2$. Again, note the paired punctate staining (arrows). Magnification: $a-f$ and $i, 7.5 \times ; g$ and $h, 75 \times ; j-l, 150 \times$. 

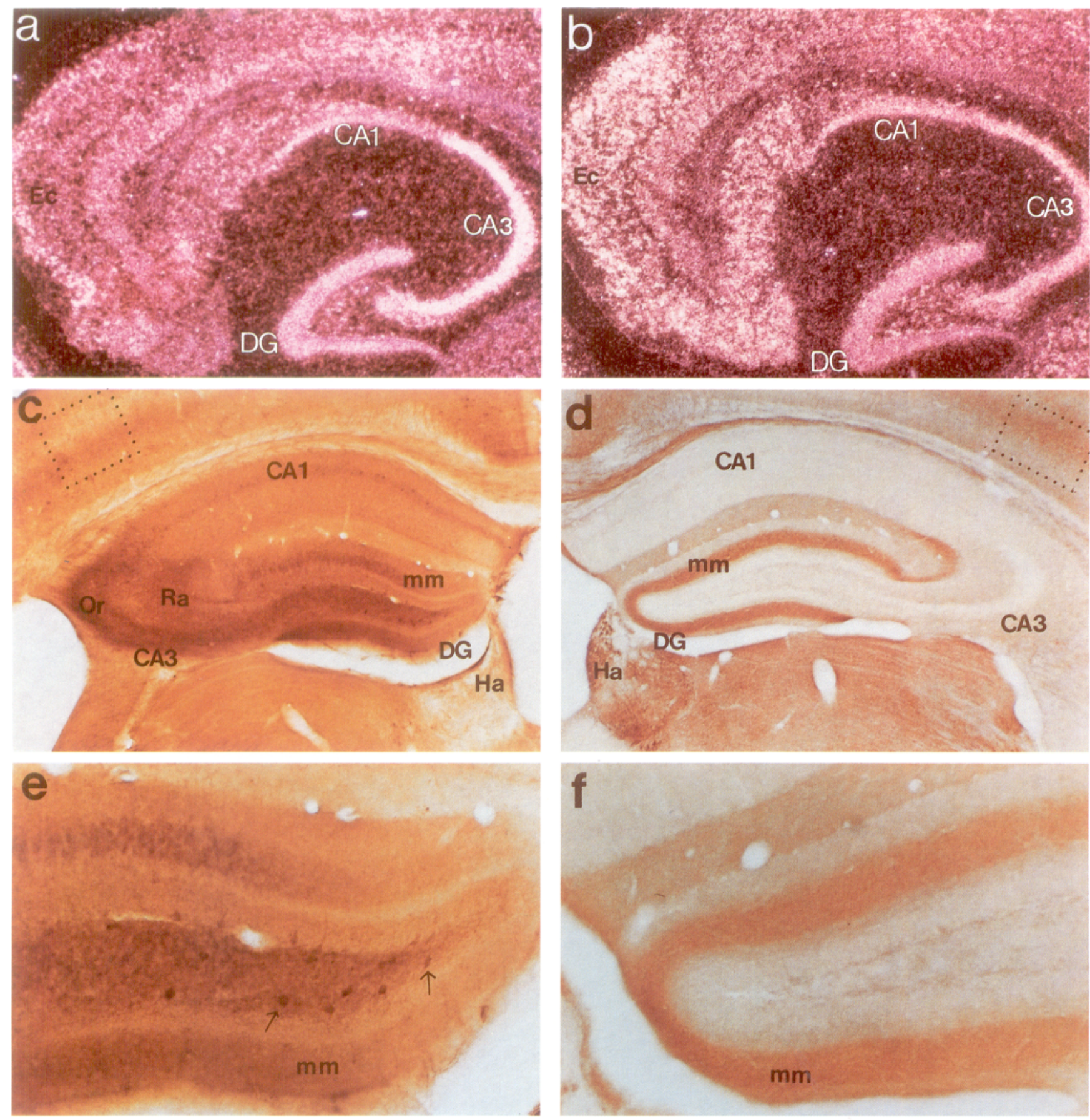

g

h 

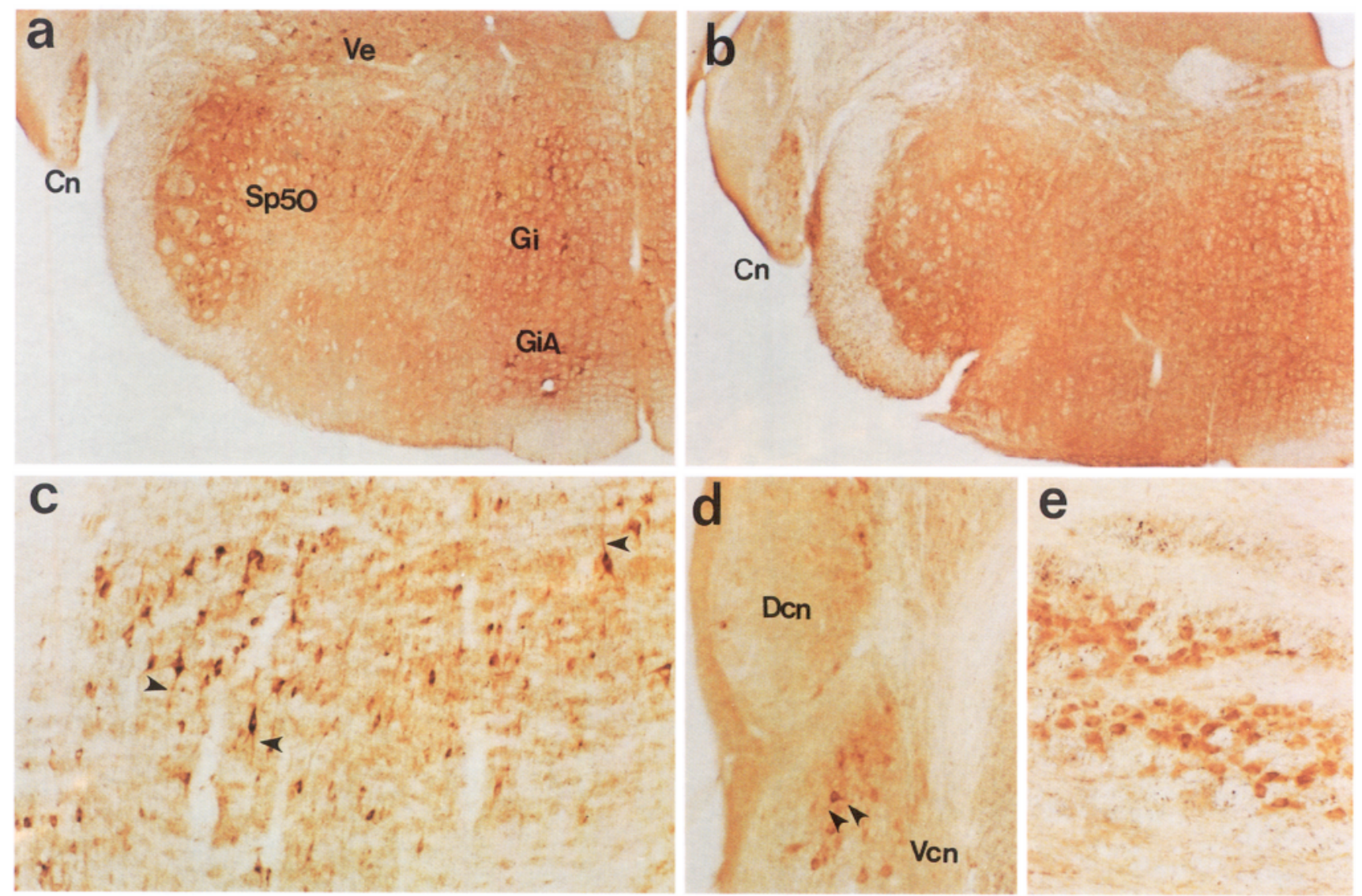

Figure 3. a, Coronal section stained with $\alpha$-Kvl.1 showing signal in the cochlear nucleus $(C n)$, vestibular nuclei ( Ve), spinal trigeminal nucleus oral $(S p 50)$, gigantocellular reticular nucleus $(G i)$, and gigantocellular reticular nucleus alpha $(G i A)$. $b$, Coronal section stained with $\alpha-\mathrm{K} v 1.2$ showing the signal in somata of the cochlear nucleus $(\mathrm{Cn})$ but only in the neuropil (not cell bodies) in other regions at this level of the brainstem. $c$, A higher magnification of a region in the pontine (gigantoreticular nucleus). Note the $\alpha$-Kvl.1 signal is not only in cell somata, but also in proximal dendrites (arrowheads). $d$, A higher magnification $(\alpha-\mathrm{Kvl} 1.2)$ in the cochlear nucleus; dorsal $\mathrm{Cn}(D c n)$, ventral $\mathrm{Cn}\left(V_{c n}\right)$. Note again the signal in the proximal dendrites (arrowheads) in the $\mathrm{V} c n . e$, A sagittal section of the medial nucleus of the trapezoid body stained with $\alpha$-Kv1.1 showing the specific staining of cell somata. Magnification: $a$ and $b, 30 \times ; c, 75 \times ; d$ and $e, 150 \times$.

4b). This axoplasmic distribution is similar to that observed for Na channels (Black et al., 1989).

\section{Cellular and subcellular localization of $m K 1.2$ in the olfactory bulb}

In the olfactory bulb, a very distinct differential pattern of staining is seen for $\mathrm{mKv} 1.1$ and $\mathrm{mKv} 1.2$ (Fig. $1 h, j$ ). While $\mathrm{mKv} 1.1$ staining is not observed, mKv1.2 protein is expressed strongly in the mitral and tufted cell layer or inner plexiform layer of the olfactory bulb. In mitral cells, staining is observed in cell somata, axons, as well as in the proximal dendrites (Fig. 1h,j). In agreement with this observation, strong signals are seen in mitral and tufted cells by in situ hybridization with $\mathrm{mKv} 1.2$ but not with mKv1.1 (data not shown). In addition, the mKv1.2 protein is also expressed in the accessory olfactory bulb (Fig. $1 b, h)$.

\section{Cellular and subcellular localization of $m K r 1.1$ and $m K r 1.2$ in the hippocampus}

In the dentate gyrus of the hippocampal formation, both mKv1.1 and $\mathrm{mKvl} .2$ are present in the middle molecular layer (Fig. $2 c, d)$. Inspection of the staining at the electron microscopic level revealed that immunoreaction products of both mKv1.1 and $\mathrm{mKv} 1.2$ are associated with fine axon processes, often at or near synaptic zones (Fig. 4b). Sometimes, however, K channel proteins are also present in a narrow, neck-like region of the axon

Figure 2. Localization of $\mathrm{mKv1.1} \mathrm{(left} \mathrm{column)} \mathrm{and} \mathrm{mKv1.2} \mathrm{(right} \mathrm{column).} a$, In situ hybridization of mKv1.1 in a horizontal section, showing expression in the pyramidal cell layer (CAl and CA3), in the dentate gyrus $(D G)$, as well as in the entorhinal cortex $(E c)$. Note that the strongest signal is in the CA 3 pyramidal cells. $b$. In situ hybridization of a horizontal section showing $\mathrm{mKv} 1.2 \mathrm{mRNA}$ expression. Abbreviations are as in $a$. Note the relatively high level of expression in the medial entorhinal cortex $(E c)$. $c$, Coronal section stained with $\alpha$-Kv1.1 antibody. Note the immunoreactive signal in the middle molecular layer $(\mathrm{mm})$ of the dentate gyrus $(D G)$ and in the hilar/CA 3 region [oriens layer $(O r)$ and radiatum $(R a)$ layer]. $d$. Coronal section stained with $\alpha-\mathrm{K} v 1.2$ showing immunoreactive products in the dentate gyrus (middle molecular layer) and habenula $(H a) . e$. Higher magnification of $\mathrm{mKv1.1}$ staining in the dentate gyrus region. Note strong staining in a subset of interneurons (arrows). $f$, Higher magnification of mKvl.2 staining in the dentate gyrus region. $g$. Higher magnification of a region from the cortex, comparable to boxed region in c. Note staining for mKv1.1 in cell somata (arrowheads) and in apical dendrites (arrows). $h$. Higher magnification of a cortical region comparable to boxed region in $d$. In contrast to $g(\alpha-\mathrm{Kv} 1.1)$, somata appear not to stain using $\alpha-\mathrm{Kv} 1.2$. Magnification: $a-d, 30 \times ; e-h, 75 \times$. 
that is adjacent to a varicosity or a presynaptic zone (Fig. $4 a$; data shown only for mKv1.2). Occasionally, juxtaparanodal staining in myelinated axons is also seen in this region (data not shown). In situ hybridization shows that both $\mathrm{mKv} 1.1$ and mKv1.2 mRNA are expressed, mKvl.2 more strongly, in the medial entorhinal cortex (Fig. $2 a, b$ ). Based on these observations from in situ hybridization and from immunocytochemistry at both the light and electron microscopic levels, it seems most likely that the $\mathrm{mKv} 1.1$ and $\mathrm{mKv} 1.2$ proteins are located in perforant path axons and axon terminal zones in the middle molecular layer.

$\mathrm{mKv1.1}$ also stains heavily in the hilar/CA3 region, both in stratum oriens and stratum radiatum, as well as in the somata and projections of interneurons (Fig. $2 c$ ). The signal discontinues at the junction between the $\mathrm{CAl} / \mathrm{CA} 3$ regions (Fig. $2 c$ ). In agreement with this protein distribution, in situ hybridization of $\mathrm{mKv} 1.1$ shows that the mKvl.1 mRNA is highly expressed in CA3 pyramidal cells and much less so in CA1 pyramidal cells (Fig. 2a). Exclusive attribution of $\mathrm{mKv} 1.1$ staining in $\mathrm{CA} 3$ region to the CA3 pyramidal cells is not clear cut, however, given that the CA3 strata oriens and radiatum contain mossy fiber axons and terminals from granule cells as well as axon collaterals and dendrites of CA3 pyramidal cells (and various other input fibers). In particular, in situ hybridization shows expression of both mKvl.1 and mKvl.2 in granule cells; this distribution does not match, however, the differential staining for $\mathrm{mKvl} .1$ and $\mathrm{mKv} 1.2$ in the CA3 region. Possible cxplanations for this discrepancy between in situ and immunocytochemical ohservations include differential translational efficiency of the transcripts or differential levels of detection by any of the in situ probes or antibody probes used in these studies.

To understand better the nature of the staining in the hippocampus, we again conducted EM immunocytochemistry. At three different inspection sites in the hilar/CA3 region, the mKv1.1 immunoreaction product was associated with fine axons, often near or at synaptic terminals. Occasionally, reaction products were also seen throughout an unmyelinated axon. Juxtaparanodal regions of myelinated axons were also heavily stained. We found no evidence of the $\mathrm{mKvl}$.1 reaction product being associated with mossy fiber bundles or typical mossy fiber terminals (Fig. 4c). Furthermore, we observed no staining of either channel protein in dendrites of the hippocampal pyramidal ncurons; all staining was localized to axons and terminal processes (Fig. $4 c-c$ ). Judging from these observations and observations by in situ hybridization, it is most likely that the $\mathrm{mKVl} .1$ protein is associated with axon collaterals and terminals of CA3 pyramidal cells; we cannot exclude, however, the possibility that other input fibers also contribute to the staining pattern in the hilar/CA3 region.
Cellular and subcellular localization of $m K v 1.1$ and $m K v 1.2$ in the cerebellum

Extensive overlapping of staining was seen for mKv1.1 and $\mathrm{mKv} 1.2$ in the cerebellum, particularly in the basket cell axon plexus and terminal regions around Purkinje cells (Fig. 5a-c; see also Wang et al., 1993). EM immunohistological studies revealed that immunoreaction products were present at synaptic release sites onto the Purkinje cell soma, as illustrated in Figure $5 d$; in addition, this same section shows reaction product associated with a zone of contact between two axons (Fig. $5 d$ ). Similarly, dense reaction product was present on both sides of specialized junctions between basket cell axons in the Purkinje cell perisomatic plexus or pinceau region (Fig. $5 c, e$; Palay and Chan-Palay, 1974). Since axons from several different basket cells are present in the same plexus, we cannot know whether the $\mathrm{K}$ channel staining that we observed was associated with junctions connecting axons from different basket cells or different branches of the same axon. In the cerebellar granule cell layer, mKv1.1 and mKv1.2 were expressed in unmyelinated axons as well as in the juxtaparanodal regions of myelinated axons.

\section{Discussion}

In situ hybridization studies conducted by ourselves and others have shown that $\mathrm{mKv} 1.1$ and $\mathrm{mKv} 1.2$ are expressed in a unique, yct overlapping subset of neurons in the CNS (Mackinnon, 1989; Adams et al., 1992; Tsaur et al., 1992). Consistent with their in situ hybridization patterns, $\mathrm{mKvl} .1$ and $\mathrm{mKv} 1.2$ channel proteins have unique distribution patterns in the mouse brain, yet these patterns overlap extensively in many regions. This colocalization in various brain regions corroborates and extends our recent demonstration that $\mathrm{mKv} 1.1$ and $\mathrm{mKv} 1.2$ proteins form heteromultimeric channels in viro (Wang et al., 1993). Although the exact stoichiometry and physiological properties of these heteromultimeric channels are not known in vivo, expression studies conducted in the Xenopus expression system have confirmed that these two channel proteins can form heteromultimeric channels that have distinct properties (Hopkins, unpublished observations). When expressed alone, mKvl.1 and $\mathrm{mKv} 1.2$ each gives rise to a rapidly activating, slowly inactivating outward $\mathrm{K}^{2+}$ current. There is, however, a $10 \mathrm{mV}$ difference in the threshold and voltage for half-activation between the two channels. A yet larger difference $(\sim 30 \mathrm{mV})$ in activation threshold is observed when these channels are expressed in transformed mammalian cells (Bosma et al., 1993). Randomly assembled, heteromultimeric channels expressed in Xenopus oocytes have biophysical properties intermediate between those of $\mathrm{mKv1} .1$ and $\mathrm{mKv} 1.2$ expressed alone, but quantitatively

\footnotetext{
Figure 4. EM immunohistological localization of $\mathrm{mKvl} .1$ and $\mathrm{mKvl} .2$ in the hippocampus. $a$, In the dentate middle molecular layer, $\alpha$-Kv1.2 immunoreaction product (solid straight arrow's) is associated with neck regions of an axon $(a)$ adjacent to a varicosity ( $\mathrm{Va}$ ) and a presynaptic zone contacting a dendritic spinc head $(s)$. In the synaptic zonc (curved arrow) and a nearby axon (open arrow), the reaction product is located near regions where synaptic vesicles (v) are present. $b$. In the middle molecular layer, $\alpha-\mathrm{Kv} 1.2$ immunoreaction product is associated with presynaptic zones (curved arrows). Note the reaction product amongst the presynaptic vesicles $(v)$ and near the presynaptic membrane specialization. Both immunoreactive boutons contact dendrite spine heads $(s)$. Immunoreaction product is also present along an axon (solid straight arrow). Occasionally, it is associated with smooth ER (open arrow). $C$. In the CA3a stratum lucidum region, $\alpha-\mathrm{Kv} 1.1$ reaction product is localized in a small axonal process (arrow) but does not appear to be associated with CA3 pyramidal cell dendrite $(D)$ or mossy fiber terminals $(M F)$. $d$, In the CA3c stratum lucidum and hilar region, $\alpha-\mathrm{K} v 1.1$ reaction product is seen in a narrow region of the axon (arrow); however, no reaction product appeared to be associated with the presynaptic zone in this plane of section (open arrow). $e$. In the CA3b stratum oriens and pyramidale region, $\alpha-\mathrm{Kv} 1.1$ reaction product is in a varicosity of an axon in which synaptic vesicles (v) are present (solid straight arrow). Weak reaction product is also present in a presynaptic zone of another axon/terminal (curved arrow) contacting a spine head (s). Scale bars: $a, c$, and $d, 0.5 \mu m ; b$ and $e, 0.25 \mu \mathrm{m}$.
} 

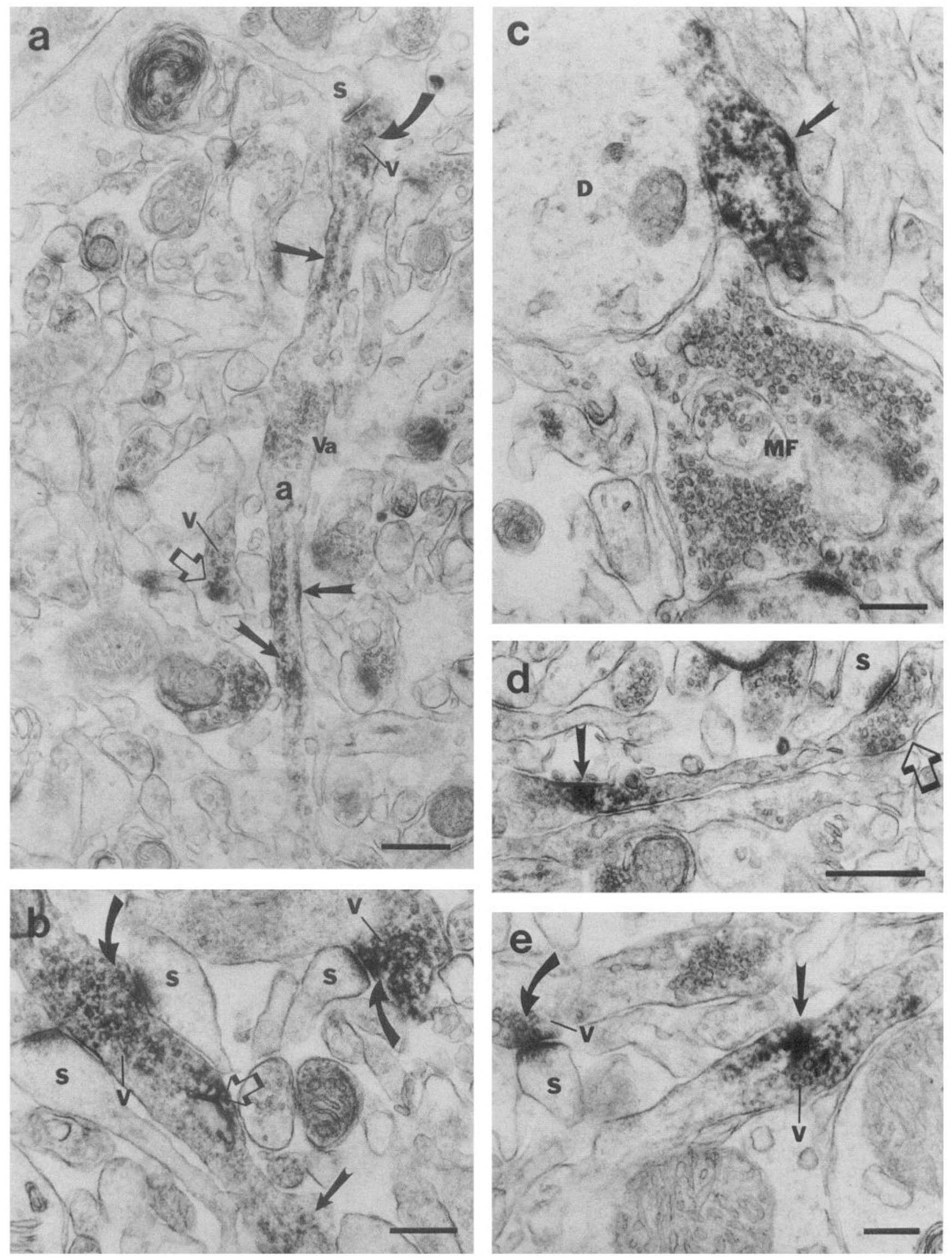

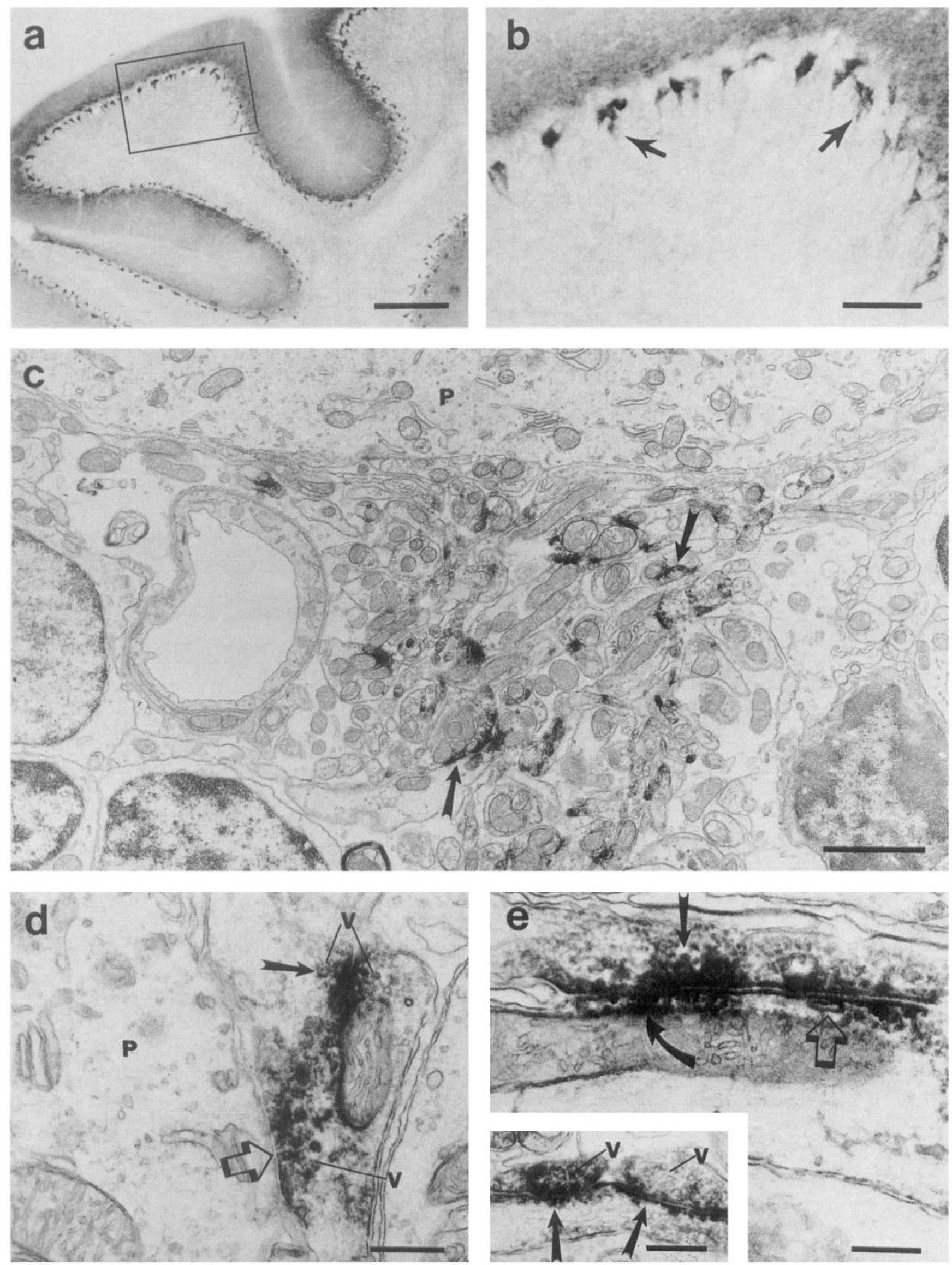
closer to the properties of the more abundant subunit (Hopkins unpublished observations). Thus, in the regions where $\mathrm{mKv} 1.1$ and $\mathrm{mKv} 1.2$ expression overlap, factors influencing the availability of either subunit for assembly into heteromultimers might contribute to fine regulation of neuronal excitability.

Additional complexity and physiological fine tuning might arise from coexpression of multiple Shaker-like gene products, each of which contains the amino-terminal sequences that are thought to direct channel assembly within the Shaker subfamily (Li et al., 1992; Hopkins et al., 1993; Shen et al., 1993). For example, the rat $\mathrm{Kvl} .2$ and rat $\mathrm{Kv} 1.4$ have been shown to form heteromultimeric channels in vivo (Sheng et al., 1993). rKv1.4 is expressed in the molecular layer of the rat dentate gyrus (Sheng et al., 1992) where $\mathrm{mKv} 1.1$ and $\mathrm{mKvl} .2$ are also expressed. Thus, allowing for potential species variation in expression levels, one might assume that in the molecular layer, $\mathrm{Kv} 1.1, \mathrm{Kv} 1.2$, and $\mathrm{Kv} 1.4$ could potentially form heteromultimeric channels with random combinations of three different subunits. While this diversity could be exploited by a cell to provide unique current properties, the consequences could also be detrimental in terms of the metabolic energy required to accurately assemble and localize each variant. One simplifying possibility is that, as has been shown for the $\mathrm{GABA}_{\mathrm{A}}$ subunit (Perez-Velazquez and Angelides, 1993), one or more Shaker-like subunits may play a dominant role in directing heteromultimeric $\mathrm{K}$ channels to a specific subcellular domain.

\section{Axonal and terminal distribution of $K$ channel proteins}

In myelinated axons, $\mathrm{mKv} 1.1$ and $\mathrm{mKv} 1.2$ channel proteins are specifically localized in juxtaparanodal regions of the node of Ranvier, suggesting a role for these channels in the saltatory conduction properties of myelinated axons (Waxman and Ritchie, 1985; Black et al., 1990). In the hippocampus and in the cerebellum, the channel proteins are also occasionally seen in unmyelinated axons, where they may also contribute to the repolarization of action potentials.

Electron micrographs from the hippocampus and the cerebellum show that $\mathrm{mKv} 1.1$ and $\mathrm{mKv} 1.2$ proteins are localized at or near synaptic zones. This localization may be important for repolarizing the membrane locally near or at the synaptic terminal and hence regulating the duration or amount of neurotransmitter release at a specific terminal. Occasionally, the proteins are also localized in a narrow, ncck-like region of the axon near a varicosity or synaptic zone. It is possible that the presence of voltage-gated $\mathrm{K}$ channels in these regions may regulate action potential invasion of terminals and hence control local transmitter release in a calcium-independent manner. The possibilities are particularly strong in the hippocampus, where the $\mathrm{K}$ channel protein is associated exclusively with small axons and their terminals in the hilar/CA3 region. EM data show no association of either $\mathrm{mKv} 1.1$ or $\mathrm{mKv} 1.2$ proteins with the large, distinctive mossy fiber terminals from granule cells. Rather, taking the light, EM, and in situ data together, these data suggest that in the mouse hippocampus, $\mathrm{mKv} 1.1$ protein is associated with the fine recurrent axon collaterals of the $\mathrm{CA} 3$ pyramidal cells.

In the plexus of basket cell axons in the cerebellum, a unique pattern of $\mathrm{mKv} 1.1$ and $\mathrm{mKv} 1.2$ expression is found. The channel proteins are specifically localized near specialized junctions that resemble septate junctions and are proposed to provide physical attachment and high-resistance cross-bridges between basket cell axons (Sotclo and Llinas, 1972). Both K channel proteins examined here are present on both sides of these specialized junctions. One can only speculate about the function of the channels in these regions. One possibility is that they are involved in establishing a localized extracellular current flow that influences the membrane properties of other axons in the plexus. This type of extracellular potential change has been studied in the goldfish, where collateral axonal activity passively hyperpolarizes the Mauthner cell axon hillock, thereby providing a type of electrical inhibition (Furukawa and Furshpan, 1963). It is not known whether this type of regulation might influence release of the inhibitory neurotransmitter GABA onto the Purkinje cells.

\section{Localization of $m K v 1.1$ and $m K v 1.2$ in neuronal cell bodies}

The mKv1.1 and mKv1.2 proteins are also localized in cell somata, suggesting that these channels might regulate excitability of the cell soma. Specific action potential-generating somata that express $\mathrm{mKv} 1.1$ and/or $\mathrm{mKv} 1.2$ include neurons from cerebellar nuclei (Llinas and Muhlethaler, 1988), cortical pyramidal cells in which the repolarizing phase of the action potential includes a delayed rectifier-like, voltage-dependent, slowly inactivating $\mathrm{K}^{+}$current (Schwindt et al., 1988), and mitral and tufted cells of the olfactory bulb in which spikes are recorded in response to odor stimulation (Hamilton and Kauer, 1985). The presence of $\mathrm{mKv} 1.1$ and/or $\mathrm{mKv} 1.2$ in these cells suggests that these channels may help determine the shape of action potentials in these cell bodies and may thereby be involved in regulating discharge patterns such as interspike intervals and burst frequencies. Given that all neuronal somata are likely to express some type of $\mathrm{K}$ channel, we speculate that the rapidly activating, delayed rectifier-type properties of $\mathrm{mKv} 1.1$ may, in particular, be expressed in somata that generate or transmit action potentials at high frequency.

\section{Localization of $m K v 1.1$ and $m K v 1.2$ in dendrites}

In mitral cells of the olfactory bulb, $\mathrm{mKv} 1.2$ protein is observed in proximal dendrites. Functionally distinct from the glomerular dendritic tuft, which is concerned with reception and processing of the olfactory input, the mitral cell primary dendritic shaft has as its main function the transfer of information from the

\footnotetext{
Figure 5. Localization of $\mathrm{mKv} 1.1$ in the cerebellum. $a$, General distribution of $\mathrm{mKv} 1.1$ in the cerebellum at the light microscopic lcvel. $b$, Higher magnification of the boxed region in a showing the specific staining in the basket axon plexus region (arrows). $c$, EM immunohistochemistry of $\alpha-\mathrm{K} v 1.1$ in the basket axon plexus region. Reaction product is associated with specialized junctions (arrows) among axon branches near a Purkinje cell $(P) . d$, Immunoreaction product of $\alpha$-Kvl.1 at an apparent synaptic contact onto a Purkinje cell soma (open arrow). The same axon has reaction product at a specialized junction with another axon (solid arrow). Note the vesicles $(v)$ at the junctional zone and the synaptic zone. $e$, Immunoreaction product of $\alpha-\mathrm{K} v 1.1$ in a specialized axon-axon junction. The dense reaction product is associated with or close to the axon membrane (straight solid arrow'); reaction product is sometimes also associated with nearby membranes of mitochondria (curved arrow) and smooth ER (open arrow). Note also the closely opposed parallel membranes with apparent cleft material at the junction. Inset, Immunoreaction product localized in two axons (arrows) containing vesicles ( 1 ). which form specialized junctions with another presumed axon. Note the immunoreaction product of $\alpha$-K $v 1.2$ amongst the vesicles and near the membrane specializations. Scale bars: $a, 250 \mu \mathrm{m} . ; b, 50 \mu \mathrm{m} ; c, 2 \mu \mathrm{m} ; d$ and inset in $e, 0.5 \mu \mathrm{m} ; e, 0.25 \mu \mathrm{m}$.
} 
glomerular tuft to the cell body (Shepherd and Greer, 1990). Although it is not clear whether these proximal dendrites conduct input signals by passive or active membrane properties, it is likely that the presence of the $\mathrm{mKv} 1.2$ channel in the dendrite regulates the conduction of information to the cell body. $\mathrm{mKv} 1.1$ is also present in proximal dendrites of the magnocellular cells of the cochlear nucleus, pontine nucleus, peritrigeminal nucleus, and other nuclei in the brainstem, as well as in the apical dendrites of neocortical pyramidal cells. Recent evidence suggests that the apical dendrites of these layer $V$ pyramidal cells receive synaptic input and conduct $\mathrm{Na}^{+}$-dependent action potentials to the cell soma (Refehr et al., 1993). Thus, both $\mathrm{mKvl} .1$ as well as $\mathrm{mKv1.2}$ can be located in dendritic regions of neurons and may contribute to the repolarization of action potentials in those dendrites.

We and others have shown that the Kv1.1 and Kv1.2 mRNAs are present in a specific subset of neurons in the CNS. Using specific antibodies, we show here that each channel is localized, and often colocalized, to specific subcellular regions of neurons in the mouse brain. The subcellular domains occupied by each channel include cell somata, axons, and dendrites. The determinants of this pattern of gene expression and channel localization are not known, nor do we understand the mechanisms by which the expressed proteins are targeted to, and maintained in, specific subcellular locations. It is likely that multiple factors are involved in these processes. Factors extrinsic to the channel sequences themselves may include influences from trophic factors, contact with neuroglia, and neuronal activity. Intrinsic structural signals in the channel protein may also be required to interact with special trafficking proteins in the cell or anchor proteins at specific subcellular locations. One candidate for this function is the $38 \mathrm{kDa}$ protein that is associated with the dendrotoxin-sensitive $\mathrm{mKv1} 1.1$ and $\mathrm{mKv} 1.2$ channels (Rehm et al., 1989) and may be functionally analogous to the $43 \mathrm{kDa}$ protein that is involved in aggregating ACh receptors (Maimone and Merlie, 1993).

\section{References}

Adams LA, Houamed KM, Tempel BL (1992) Potassium channel genes: genomic complexity, molecular properties and differential expression. In: Potassium channel modulators (Weston AH, Hamilton TC, eds), pp 14-33. Oxford: Blackwell Scientific.

Baumann A. Grupe A, Ackermann A. Pongs O (1988) Structure of the voltage-dependent potassium channel is highly conserved from Drosophila to vertebrate central nervous systems. EMBO J 7:24572463.

Black JA, Waxman SG, Friedman B, Elmer LW, Angelides KJ (1989) Sodium channels in astrocytes of rat optic nerve in situ: immunoelectron microscopic studies. Glia 2:353-369.

Black JA, Kocsis JD, Waxman SG (1990) Ion channel organization of the myelinated fiber. Trends Neurosci 13:48-54.

Bosma MM, Wang H, Tempel BL (1993) Transfection of a cloned $\mathrm{K}^{+}$ channel (mKv1.2) into normal and protein kinase A-deficient cells. Soc Neurosci Abstr 19:712.

Butler A, Wei AG, Baker K, Salkoff L (1989) A family of putative potassium channel genes in Drosophila. Science 243:943-947.

Chandy KG. Williams CB. Spencer RH, Aguilar BA, Ghanshani S, Tempel BL, Gutman GA (1990) A family of three mouse potassium channel genes with intronless coding regions. Science 247:973-975.

Christie MJ. Adelman JP, Douglass J, North RA (1989) Expression of a cloned rat brain potassium channel in Xenopus oocytes. Science 244:221-224.

Christie MJ, North RA, Osborne PB, Douglass J, Adelman JP (1990) Heteropolymeric potassium channels expressed in Xenopus oocytes from cloned subunits. Neuron 2:405-411.

Covarrubias M. Wei A, SalkoffL (1991) Shaker, Shal, Shab, and Shaw express independent $\mathrm{K}^{+}$current systems. Neuron 7:763-773.
Drewe JA, Verma S, Frech G, Joho R (1992) Distinct spatial and temporal expression patterns of $\mathrm{K}^{+}$channel mRNAs from different subfamilies. J Neurosci 12:538-548.

Furukawa T, Furshpan EJ (1963) Two inhibitory mechanisms in the Mauthner neurons of goldfish. J Neurophysiol 26:140-176.

Hamilton KA, Kauer JS (1985) Intracellular potentials of salamander mitral/tufted neurons in response to odor stimulation. Brain Res 338: $181-185$.

Hille B (1991) Ionic channels of excitable membranes. Sunderland, MA: Sinauer.

Hopkins WF, Demas V, Tempel BL (1993) Both N- and C-terminal regions contribute to the assembly and functional expression of homoand heteromultimeric voltage-gated $\mathrm{K}^{+}$channels. J Neurosci 14:13851394.

Hwang PM, Glatt CE, Bredt DS, Yellen G, Snyder SH (1992) A novel $\mathrm{K}^{+}$channel with unique localizations in mammalian brain: molecular cloning and characterization. Neuron 8:473-481.

Hwang PM, Fotuhi M, Bredt DS, Cunningham AM, Snyder SH (1993) Contrasting immunohistochemical localizations in rat brain of two novel $\mathrm{K}^{+}$channels of the Shab subfamily. J Neurosci 13:1569-1576.

Isacoff EY, Jan YN, Jan LY (1990) Evidence for the formation of heteromultimeric potassium channels in Xenopus oocytes. Nature 345:530-534.

Itoh K, Konish A, Nomura S, Mizono N, Nakamura Y, Sugimoto T (1979) Oxidation reaction to electron microscopic demonstration of horseradish peroxidase: cobalt-glucose oxidase method. Brain Res 175:341-346.

Jan LY, Jan YN (1989) Voltage-gated ion channels. Cell 56:13.

Kamb A, Iverson LE, Tanouye MA (1987) Molecular characterization of Shaker, a Drosophila gene that encodes a potassium channel. Cell 50:405-413.

Li M, Jan YN, Jan LY (1992) Specification of subunit assembly by the hydrophilic amino-terminal domain of the Shaker potassium channel. Science 257:1225-1230.

Llinas R, Muhlethaler M (1988) An electrophysiological study of the in vitro, perfused brainstem-cerebellum of adult guinea pig. J Physiol (Lond) 404:241-264

Mackinnon D (1989) Isolation of a cDNA clone coding for a putative second potassium channel indicates the existence of a gene family. $J$ Biol Chem 264:8230-8236.

Maimone MM, Merlie JP (1993) Interaction of the $43 \mathrm{kd}$ postsynaptic protein with all subunits of the muscle nicotinic acetylcholine receptor. Neuron 11:53-66.

Pak MD, Covarrubias M, Ratcliffe A, Salkoff L (1991) A mouse brain homolog of the Drosophila Shab K + channel with conserved delayedrectifier properties. J Neurosci 11:869-880.

Palay SL, Chan-Palay V (1974) Cerebellar cortex: cytology and organization. Heidelberg: Springer.

Papazian DM, Schwarz TL, Tempel BL, Jan YN, Jan LY (1987) Cloning of genomic and complementary DNA from Shaker, a putative potassium channel gene from Drosophila. Science 237:749-753.

Perez-Velazquez JL, Angelides KJ (1993) Assembly of GABA-A receptor subunits determines sorting and localization in polarized cells. Nature 361:457-460.

Pongs O, Kecskemethy N, Muller R, Krah-Jentgens I, Baumann A, Kiltz HH, Canal I, Llamazares S, Ferrus A (1988) Shaker encodes a family of putative $\mathrm{K}^{+}$channel proteins in the nervous system of Drosophila. EMBO J 7:2457-2463.

Regehr W, Kehoe J, Ascher P, Armstrong C (1993) Synaptically triggered action potentials in dendrites. Neuron 11:145-151.

Rehm H, Newitt RA, Tempel BL (1989) Immunological evidence for a relationship between the dendrotoxin-binding protein and the mammalian homologue of the Drosophila Shaker $\mathrm{K}^{+}$channel. FEBS Lett 249:224-228.

Rudy B (1988) Diversity and ubiquity of K channels. Neuroscience 25:729-749.

Ruppersberg JP, Schröter KH, Sakmann B, Stocker M, Sewing S, Pongs O (1990) Heteromultimeric channels formed by rat brain potassium-channel proteins. Nature 345:535-537.

Schwarz TL, Tempel BL, Papazian DM, Jan YN, Jan LY (1988) Multiple potassium channel components are produced by alternative splicing at the Shaker locus in Drosophila. Nature 331:137-142.

Schwindt PC, Spain WJ, Foehring RC, Strafstrom CE, Chubb MC, Crill WE (1988) Multiple potassium conductances and their functions in neurons from cat sensorimotor cortex in vitro. J Neurophysiol 59: $424-449$. 
Shen NV, Chen X, Boyer MM, Pfaffinger PJ (1993) Deletion analysis of $\mathrm{K}^{+}$channel assembly. Neuron 11:67-76.

Sheng M, Tsaur M-1, Jan YN, Jan LY (1992) Subcellular segregation of two A-type $\mathrm{K}^{+}$channel proteins in rat central neurons. Neuron $9: 271-284$

Sheng M, LiAo YJ, Jan YN, Jan LY (1993) Presynaptic A-current based on heteromultimeric $\mathrm{K}^{+}$channels detected in vivo. Nature, in press.

Shepherd GM, Greer CA (1990) Olfactory bulb. In: The synaptic organization of the brain (Shepherd G, ed), pp 133-169. New York: Oxford UP.

Sotelo C, Llinas R (1972) Specialized membrane junctions between neurons in the vertebrate cerebellar cortex. J Cell Biol 53:271-289.

Sternberger LA (1979) Immunocytochemistry. New York: Wiley.

Stühmer W, Ruppersberg JP, Schröter KH, Sakmann B, Stocker M, Giese KP, Perschke A, Baumann A, Pongs O (1989) Molecular basis of functional diversity of voltage-gated potassium channels in mammalian brain. EMBO J 8:3235-3244.

Swanson R, Marshall J, Smith JS, Williams JB, Boyle MB, Folander $\mathrm{K}$, Luneau CJ, Antanavage J, Oliva C, Buhrow SA, Bennett C, Stein RB, Kaczmarek LK (1990) Cloning and expression of cDNA and genomic clones encoding three delayed rectifier potassium channels in rat brain. Neuron 4:929-939.
Tempel BL, Papazian DM, Schwarz TL, Jan YN, Jan LY (1987) Sequence of a probablc potassium channcl component encoded at Shaker locus of Drosophila. Science 237:770-775.

Tempel BL, Jan YN, Jan LY (1988) Cloning of a probable potassium channel gene from mouse brain. Nature 332:837-839.

Timpe LC, Schwarz TL, Tempel BL, Papazian DM, Jan YN, Jan LY (1988) Expression of functional potassium channels from Shaker cDNA in Xenopus oocytes. Nature 331:143-145.

Trimmer JS (1991) Immunological identification and characterization of a delayed rectifier $\mathrm{K}^{+}$channel polypeptide in rat brain. Proc Natl Acad Sci USA 80:10764-10768.

Tsaur M-L, Sheng M, Lowenstein DH, Jan YN, Jan LY (1992) Differential expression of $\mathrm{K}^{+}$channel mRNAs in the rat brain and down regulation in the hippocampus following seizures. Neuron 8:10551067.

Wang H, Kunkel DD, Martin TM, Schwartzkroin PA, Tempcl B (1993) Heteromultimeric $\mathrm{K}^{+}$channels in terminal and juxtaparanodal regions of neurons. Nature 365:75-79.

Waxman SG, Ritchie JM (1985) Organization of ion channels in the myelinated nerve fiber. Science 228:1502-1507. 